\title{
Excavatability Classification of Rocks around Haroglu Mountain in Northeast of Baskil in Elazig According to Engineering Geology Properties
}

\author{
Ebubekir Kilic \\ Programme of Geotechnics, Department of Civil, \\ Keban Vocational School, Keban / Elazig, Turkey \\ E-mail: e.kilic@firat.edu.tr
}

\begin{abstract}
Knowledge of the geology of the ground to be excavated in surface mines and foundations, especially in civil engineering works, is very important to decide on the appropriate excavation method and equipment and ensure human and equipment safety with time and cost savings. For this purpose, the engineering geological properties and excavatability classification of rocks around the Haroglu Mountain located in the northeast of Baskil in Elazig were studied. The research started with a desktop study and then continued with a walkover, the determination, and mapping of lithostratigraphic units outcropping in this study area. Yuksekova Formation, Kuscular Formation, Seske Formation, Kirkgecit Formation, and surficial deposits are the lithostratigraphic units in order of occurrence from old to young. Yuksekova Formation, the oldest unit between them, makes up of a group of plutonic, hypabyssal, volcanic, and pyroclastic rocks. After Yuksekova Formation occurs which is magmatic, the sedimentary sequence begins to form with Middle Paleocene-aged rocks. Sedimentary rocks are divided into three formations according to their stratigraphic properties. In order of occurrence from old to young, these sedimentary formations are composed of Kuscular conglomerate, Seske Formation, Kirkgecit Formation. Also, surficial deposits as the youngest unit are formed occasionally over other formations. The structural geological properties of the formations, one of the most important parameters of the excavability, were mapped. The set number, roughness, magnitude of the angle of dip, azimuth of strike or dip of discontinuities or joints, and the block volume are the significant parameters that are influenced excavatability. The azimuths of strikes of discontinuities were measured and carried out the rose diagrams from them. As a result of these measurements, the discontinuities or fractures in Yuksekova Formation have been usually found in the azimuth of a strike having NNE and a 45-90 SW of angle and azimuth of dip. It was determined that the orientation of K60W of excavation is the orientation of a very favorable excavation based on the discontinuity attitudes in the study area. It was established that the orientation of a very unfavorable excavation also is in the azimuth of the strike of fracture, namely N30E. Excavatability of the rocks was determined by assessment of lower and upper discontinuity spacing index and point load strength values. Yuksekova Formation requires methods that can be excavated from very hard to extremely hard ripping (D 9)-blasting by taking into consideration formations exposed in the study area. Kuscular Formation can be excavated by methods of easy ripping (D 6-D 7) to hard ripping (D 8) and Seske Formation also easy ripping (D 6-D 7)-very hard ripping (D 9). Kirkgecit Formation has the capabilities of being excavated by methods of hard digging (CAT 245) to very hard ripping (D 9). As a result of this study, the order of excavatability as the rocks from hard to easy can be expressed as the micro-diorite, granite, andesite, and diorite of Yuksekova Formation, the conglomerate of Kirkgecit Formation and the conglomerate of Kuscular Formation. Finally, the limestone and shale of Kirkgecit Formation would be also excavated the easiest respectively. Additionally, it has been revealed that surficial deposits can be also excavated optimally by easy digging method.
\end{abstract}

Keywords: blasting, digging, discontinuity spacing index, excavatability, formation, ripping,

DOI: $10.7176 / \mathrm{JSTR} / 7-02-03$

16 | P a g e

www.iiste.org 


\section{Introduction}

The rock excavation capacity or excavatability depends on the geotechnical characteristics of the material, the working method, and the type and size of the excavating equipment used. The cutting parts of the equipment have to be intruded into discontinuities in the rock mass or into the texture of weak rocks during mechanical excavation. The strength, volume of rock blocks, and infilling between them determine whether they can be penetrated by ripper tine or excavator bucket and dislodged by individual rock blocks. Two parameters are considered for excavatability of rocks, such as the fracture spacing index and the point load strength of intact rock by Franklin et al. (1971). Weaver (1975) arranged the numerical rippability chart, which takes into consideration such parameters as the seismic velocity, rock hardness, and weathering, spacing, capacity, gouge, the azimuths of the strike, and dip of discontinuities. The terms describing a rock mass and its involved discontinuities were developed by ISRM, (1981) because the characterization of rock mass affects excavation. MacGregor et al. (1994) revealed that the parameters of excavatability are type, grain size, weathering, unconfined compressive strength and its structure of the rock, bulldozer condition, operator, and productivity. Blyth and Freitas (1985) stated that the excavation of the rocks, rock masses or soils and the stability of the holes are affected by factors such as the strength, storage, permeability, the level of groundwater, geological structure, the magnitude of the stresses and pressure head in the ground. Pettifer and Fookes (1994) emphasized that the value of the three-dimensional discontinuity spacing index provides a more realistic evaluation. Abdullatif and Cruden (1983) reported that a rock mass can be excavated by the method of digging up to Rock Mass Rating (RMR) values of 30, ripping up to RMR values of 60, and blasting if values of RMR is more than 60 .

Knowledge of the geology of the ground to be excavated in surface mines and foundations, especially in civil engineering works, is essential to decide on the appropriate excavation method and equipment and ensure human and equipment safety with time and cost savings. The engineering geology properties and excavatability classification of the rocks around Haroglu Mountain in the northeast Baskil in Elazig were investigated in this study (Figure 1). Additionally, the term excavatability is used to express that the rocks, rock masses, and soils would be excavated with the methods of digging for easy to very easy conditions of excavation, ripping for moderate to difficult conditions of excavation, and blasting to hydraulic breaking for very difficult conditions of excavation. For the classification of the excavation of the rocks and soils, the chart of Weaver (1975), the parameters of MacGregor et al. (1994), and the graph of Pettifer and Fookes (1994) were used.

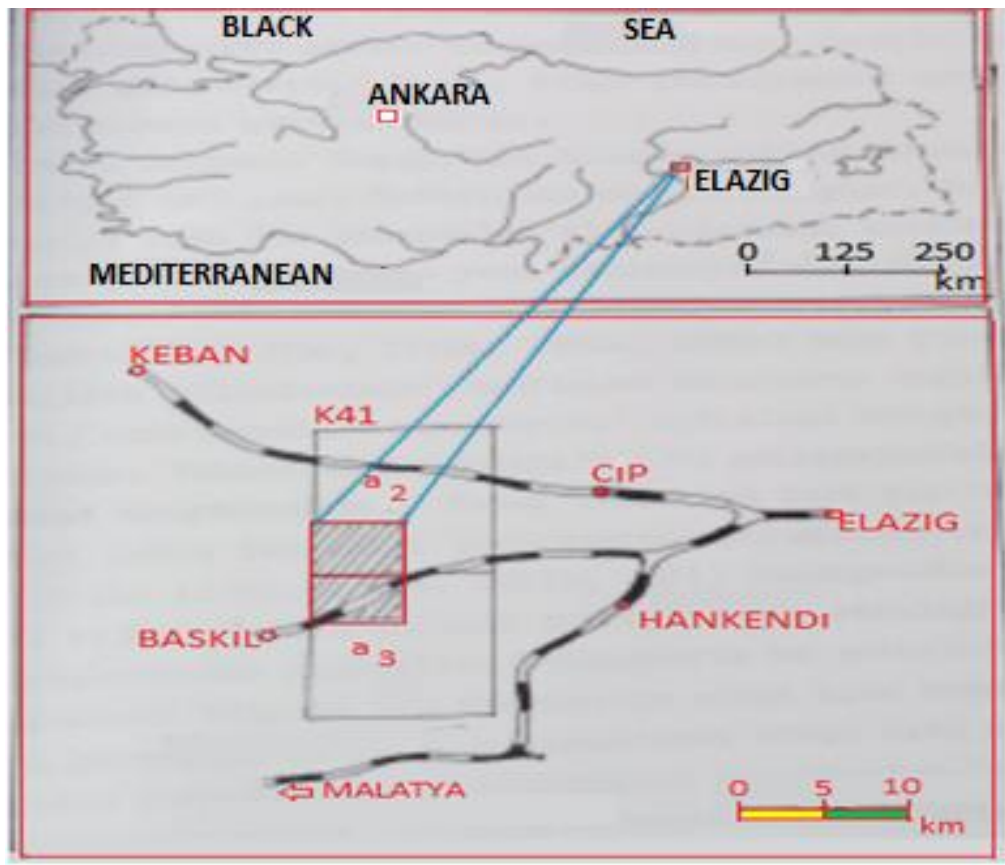

Figure 1. Location map of the study area 


\section{Material and Method}

The research started with desk study and then continued with a walkover, the determination, and mapping of lithostratigraphic units outcropping in this study area. The 1/12 500 scale map of the study area was made following formation boundaries from outcrops and the engineering properties of the lithostratigraphic units exposed here were determined. The thin sections of rock samples were examined under a microscope and the name of the rock was determined. Index experiments such as uniaxial compressive strength, porosity, etc. were measured in block samples of these rocks. The attitudes of the fractures were measured with the Brunton compass in the field and rose diagrams were drawn in the "dips program". The discontinuity spacing index, $\mathrm{I}_{\mathrm{f}}$, in y-axis and point load strength, $\mathrm{I}_{\mathrm{s} 50}$, in $\mathrm{x}$-axis on the graph of Pettifer and Fookes (1994) were plotted with "Origin pro 8.5" graphics program. For the excavation of rocks and soils, the chart of Weaver (1975) and the parameters of MacGregor et al. (1994) were also used.

\section{Results and Discussion}

\subsection{Geology}

It is illustrated at a stratigraphic section in Figure 2, in which the stratigraphic succession in the study area from bottom to top is composed of Yuksekova Formation, Kuscular Formation, Seske Formation, Kirkgecit Formation, and surficial deposits. It can be seen the distribution of rocks in all formations exposed in the study area on the map in Figure 3.

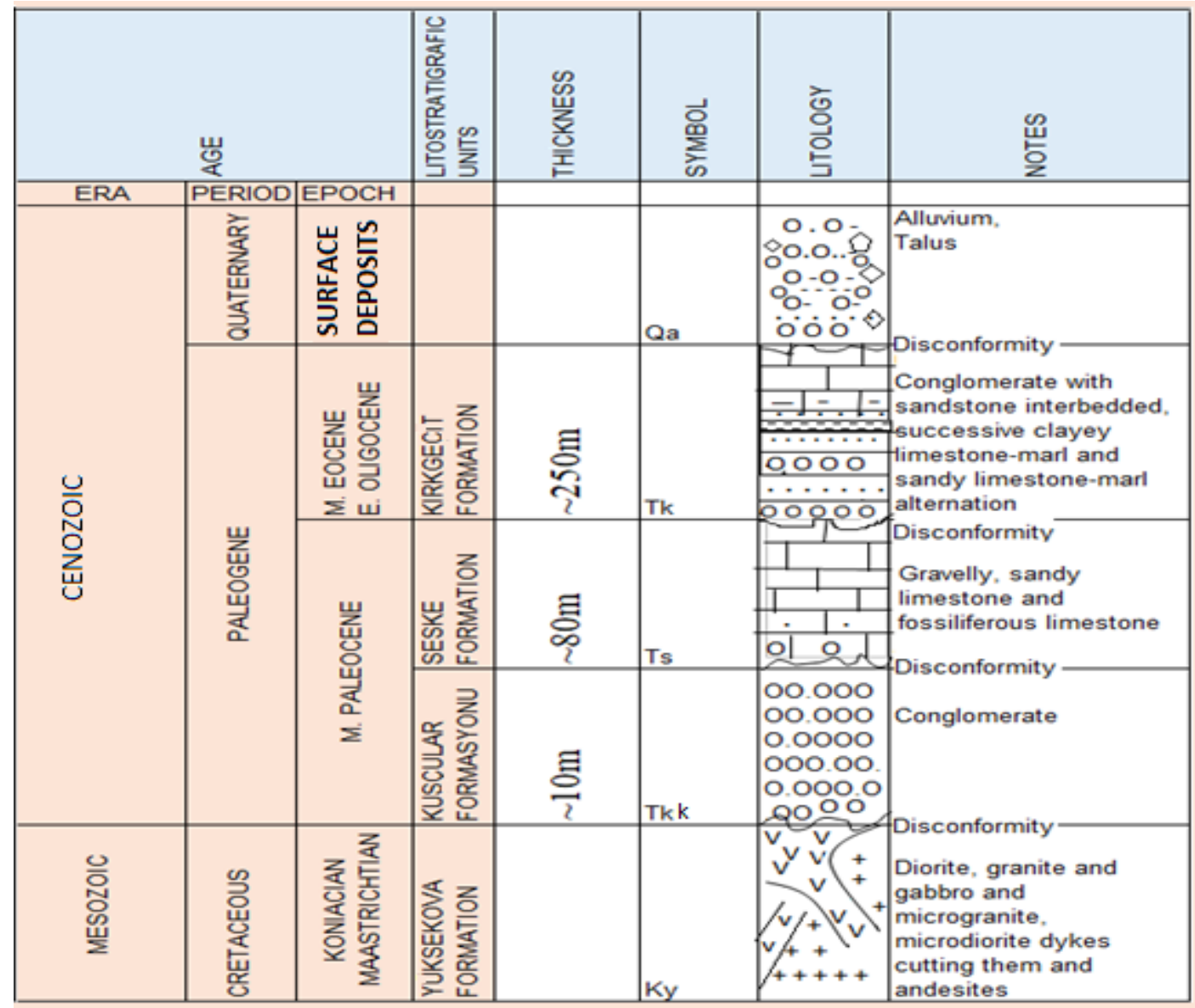

Figure 2. General stratigraphic section of the study area

\subsubsection{Yuksekova Formation}

It crops out in the middle and NE parts of the study area and has almost equal area outcrops with Seske Formation. The formation consists of plutonic, hypabyssal, and volcanic rocks that differ systematically and pyroclastic rocks. 
These rocks consist of granite, quartz diorite, and diorite rocks with medium grain diameter in the field. Of the plutonic rocks in the study area, granites are observed to consist of quartz, alkali feldspar, and plagioclase under the microscope. Hornblende and biotite are available as ferromagnesian minerals. Epidote, sericite, chlorite, and kaolin are the secondary minerals observed. They are distinguished from the surrounding rocks by their light color. Mineral distribution ratios in the rock can give quartz $33.7 \%$, plagioclase $49.0 \%$, K-feldspar $12.7 \%$, biotite $2.8 \%$, amphibole $1.0 \%$ and other minerals $0.8 \%$. The Mohs hardness equivalent of the rock is $\mathrm{H}_{\mathrm{M}}=(0.337 \times 7)+(0.49 \times 6)+(0.127 \times 6)+(0.028 \times 2.5)+$ $(0.01 \times 6)=6.191$. As a result of the above calculation, the rating of these rocks can be considered in the class of hard rocks.

Quartz diorites are easily determined from the other rocks by their darker colors. When their hand specimens are analyzed amphiboles 1-2 mm in length and dark green, white-beige plagioclases and less abundant quartz minerals are seen. Amphiboles, which make over their color to the rock, are the minerals with the most abundant.

Of plutonic rocks in the study area, diorites also cover the largest area. The rocks differ from granites with their dark gray greenish tones due to the amphiboles shimmering in the field. Besides, plagioclase, amphibole, and around 5\% quartz minerals are observed under the microscope. They contain kaolin and sericite as secondary minerals due to weathering. The grading of the hardness of these rocks according to their mineral content can be evaluated in hard rock class.

\subsubsection{Hypabyssal rocks}

Micro-granites, aplites, and micro-diorites with fine grain diameter as hypabyssal rocks are exposed by cutting plutonic rocks in the study area. Yuksekova Formation has abundant hypabyssal rocks that are acidic or basic compositions.

One of the hypabyssal rocks is the orbicular gabbro. It is rich in mafic minerals, hornblende, and pyroxene. In the thin section of the rock, mafic minerals are observed in the core of the ring and the main plagioclase and olivine minerals around it.

Micro-diorites are dark green and highly weathered. It contains mostly plagioclase and small amounts of amphibole in thin sections. Sosuritization in plagioclases and chloritization in amphiboles are observed. Micro-granites are microscopically composed of alkali feldspar, quartz, plagioclase, and amphibole as main minerals.

Aplites are composed of quartz and feldspars that weathered undetectable degrees. As secondary minerals, garnets are scattered in rock. Depending on the mineral content, the degree of the hardness of the hypabyssal rocks can be evaluated in the hard rock class.

\subsubsection{Volcanic rocks}

Volcanic rocks with less fine grain size outcrop in Hazırbaba hill, are grayish-green in color and show porphyritic texture and considerable weathering in thin sections. These rocks are andesites and hard rocks. The unit was given from fossils in flysch intercalated with volcanic rocks of Yuksekova Formation by Asutay (1985) as Santonian-Campanian in age.

\subsubsection{Kuscular Formation}

Kuscular Formation crops out only on some valley slopes southeast of the study area. It was unconformably deposited on Yuksekova Formation in the study area. The color of the formation is wine-colored due to the iron content in the matrix. The unit generally lacks fossils and is of terrestrial origin. The formation is at the base of Seske Formation and has sharp contacts with Seske Formation in the study area. The sorting of the sandy carbonate cemented unit is irregular. The bedding planes are not well developed in the unit deposited in an environment where the gravel size is from sand to mostly coarse gravel. The amount of gravel is more than the amount of matrix. Gravels of the rock are composed of monogenic, heterogeneous metamorphic rocks (mostly slightly rounded schist). The age of the unit is Middle Paleocene.

\subsubsection{Seske Formation}

It covers the north and south of Yuksekova Formation in the center of the study area. The formation presents generally a medium-thick or sometimes also, massive bedded structure. The unit is light gray and yellowish colored, starts with small amounts of gravelly and sandy limestones at the bottom, and sometimes passes into gray-white limestones containing calcarenite and marl bands. Karstic voids are observed in the upper levels. It contains abundant marine microfossils. Under the microscope, it looks

19 | P a g e

www.iiste.org 
like a biomicrite containing fossils and shell fragments in a micritic matrix. The age of the unit is Middle Paleocene.

\subsubsection{Kirkgecit Formation}

Kirkgecit Formation outcrops the most in the map area and covers the eastern parts of the study area. The unit starts with basal conglomerates, which unconformably overlies Seske Formation. The conglomerates are thick-bedded, have fragments derived from older rocks (mostly Yuksekova Formation), and gradually pass to flysch. This formation which is widespread in the study area is represented mainly by conglomerates, flysch, and carbonate rocks. Clayey and sandy limestones are thin to thick-bedded, contain chert bands at their base, and are of marine origin. The age of the unit is Middle Paleocene- Early Oligocene.

\subsubsection{Surficial Deposits}

Surficial sediments in the study area are alluvium and talus. The alluvium accumulated in the streambeds consists of various proportions of clay, silt, sand, and gravels. Talus, which has different sizes and angular fragments on the mountain and hill slopes, is formed by the disintegration of rocks. Surficial deposits are also observed along the valley beds.

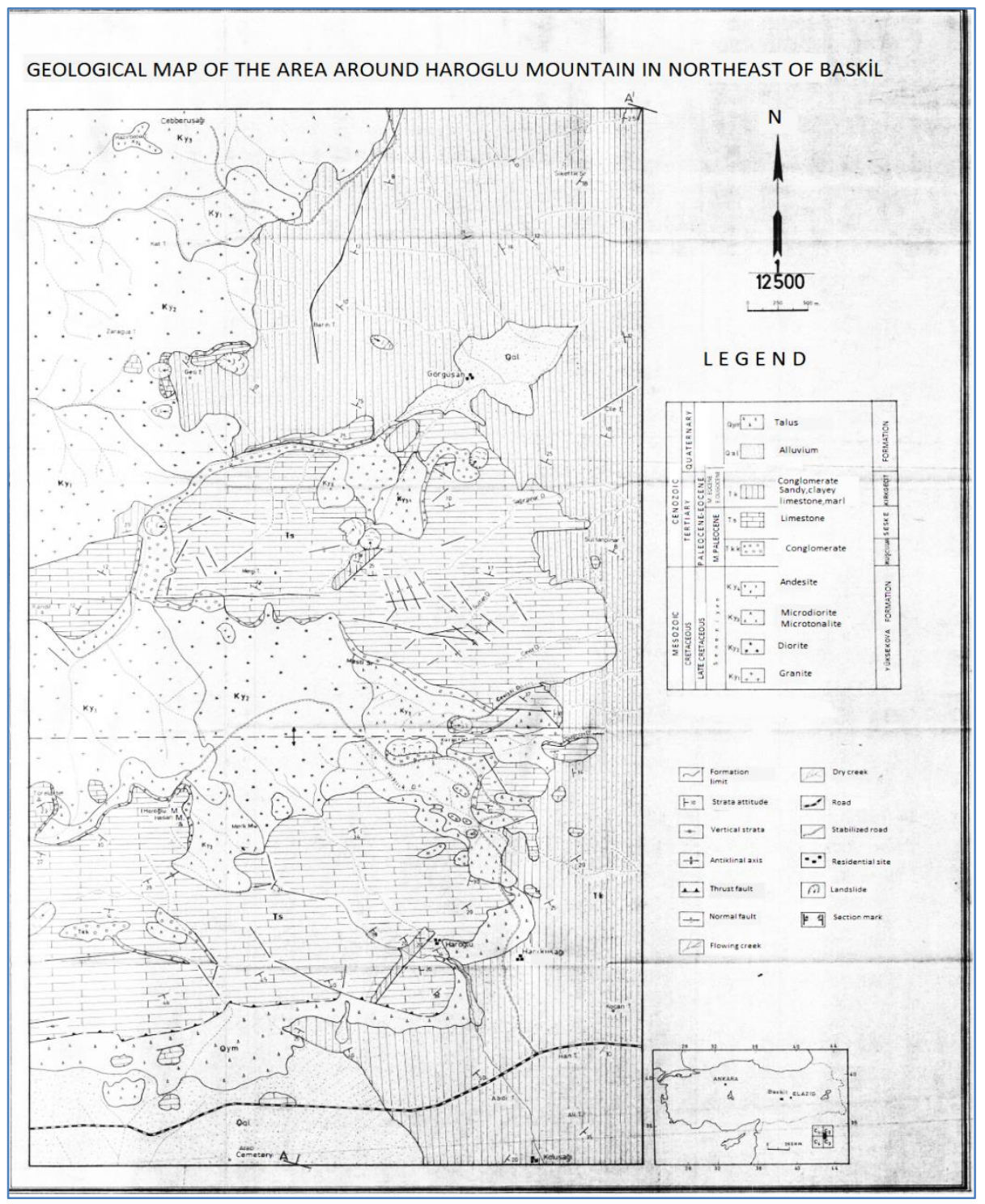

Figure 3. The map of the distribution of rocks exposed in the study. 

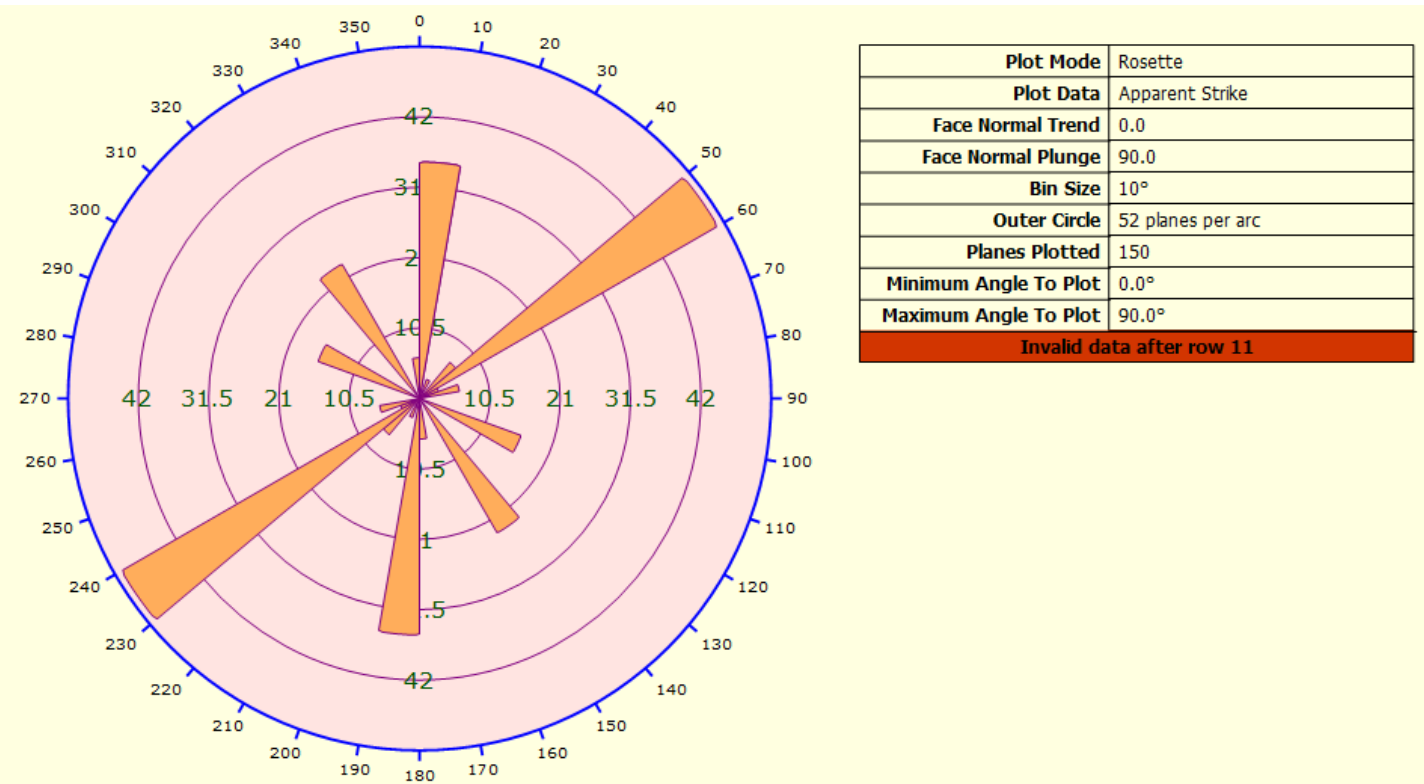

Figure 4. The strike rose diagram of the fractures in rocks in and around Elazig, which can be taken by variety publications and satellite pictures (It is drawing by measuring the orientation of fractures on the tectonic map of Tatar (1986).

\subsection{Structural Geologic Properties of Formations}

The most important structural geological properties are bedding planes, unconformities, anticline, thrust fault, and fractures. Yuksekova Formation is composed of massive, coarse, medium, and finegrained rocks. Kuscular Formation is bedded and has the same attitude as the above layers. Seske Formation is the medium-thick and sometimes massive bed. Kirkgecit Formation is mostly thickbedded. The most common discontinuity for sedimentary rocks is bedding planes. The azimuths of dip of the bedding planes are in the $30 \mathrm{NE}$ and $30 \mathrm{SW}$ direction. It is observed in Figure 4 that the azimuth of the strike of the strata in the Kirkgecit Formation is S60E or N60W. As seen in Figure 2, there are unconformities between all formations. The anticline is one of the most significantly folding structures extending in an east-west direction across the study area, its limbs have been developed in the azimuths of dip of $30 \mathrm{NE}$ and $30 \mathrm{SW}$. Sedimentary rocks formed an anticline due to tectonic forces in the southnorth direction acting on the region. The thrust has an approximate east-west extension and the older rocks in the region have been thrust over the Kirkgecit Formation.

Fractures mostly extend perpendicular to the direction of the bedding. For thrust faults, the tectonic primary forces act perpendicular to the thrust direction. Primary forces forming strike-slip faults act at an acute angle with the direction of extension of the strike-slip fault (Blyth and Freitas, 1985). Primary forces act perpendicular to the fold axis to form folds, that is, they are perpendicular to the directions of dip of the strata. The joints that develop perpendicular to the axis in a fold are cross-joints. The fractures that follow the fold axis are longitudinal joints (Bell, 2007). Tatar (1986) prepared the structural geological map of the region using various publications and satellite photographs. By being measured the fracture directions on his map (Tatar, 1986), a rose diagram was drawn (Figure 5). From the rose diagram, it is seen that the most common fractures develop regionally in the azimuth of the strike having N50-60E. For the excavatability assessment, important fracture parameters used are the set number, roughness, magnitude of the angle of dip, azimuth of strike or dip of joint, and block volume. Yuksekova Formation has fractures in the azimuth of the strike of NNE.

It is useful to use the favorability of the discontinuity orientations to make an excavation. It is known that the azimuths of general fracture strike and dip in the rocks in the region take into consideration for the orientation of excavation. Table 1 was used to correlate the orientation of a favorable excavation with the azimuth of strike and dip of fracture on the field. The fractures in Yuksekova Formation are in the azimuth of strike having NNE and is of the 45-90 angle and dip azimuth of SW. Therefore, the very favorable orientation of excavation according to Table 1 is the excavation that is perpendicular to the strike of joint, if excavation drives with the azimuth of dip of joint and the angle magnitude of dip of

21 I P a g e www.iiste.org 
the joint are $45-90^{\circ}$. It can be formulated to be in the N60W direction. Since the azimuth of the strike of fracture is NNE (N 30 D), it was seen that the orientation of a very favorable excavation is $300^{\circ}$ direction on the circle of the rose diagram in Figure 4. The orientation of an unfavorable excavation is an excavation made at $0-20^{\circ}$ angles irrespective of the azimuth of the strike of the joint. In other words, they are excavations made at an angle of $0-20^{\circ}$ other than the azimuth of the strike of joint because there is no fracture in the orientation of excavation. The orientation of an unfavorable excavation is also in the azimuth of the strike of the joint and at an angle of 20-45 ${ }^{\circ}$ against the azimuth of dip of the joint, which this direction is S $60 \mathrm{E}$. The orientation of an unfavorable excavation is the excavation made parallel to the azimuth of the strike of joint and at an angle of $45-90^{\circ}$ too.
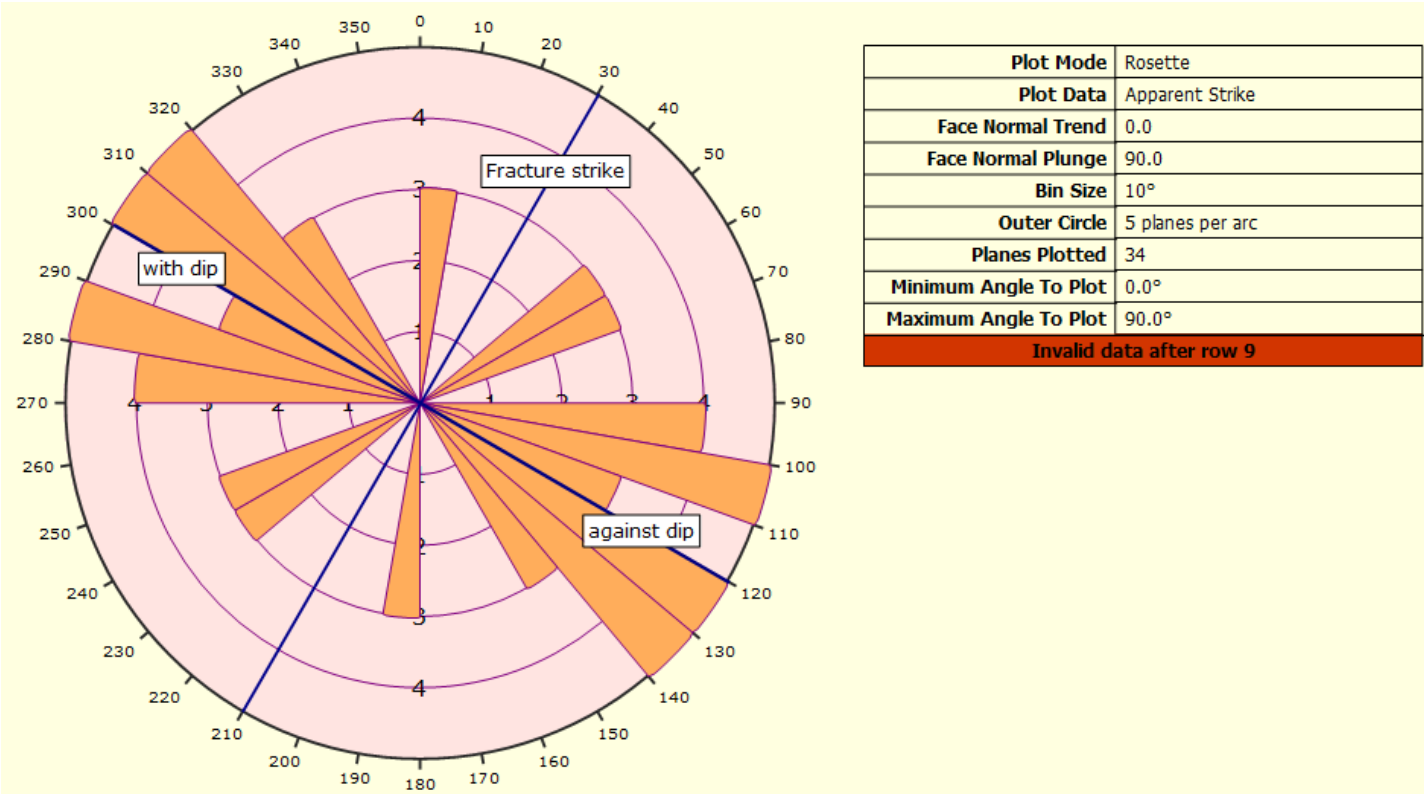

Figure 5. Rose diagram of the strata's strike directions in the outcrops of the Kirkgecit formation (34 measurements in total)

Table 1. The effect of joint strike and dip orientations in tunneling (Bieniawski, 1989)

\begin{tabular}{|l|l|l|l|l|l|l|}
\hline \multicolumn{2}{|l|}{ Strike perpendicular to tunnel axis } & \multicolumn{2}{l|}{$\begin{array}{l}\text { Strike parallel with tunnel } \\
\text { axis }\end{array}$} & $\begin{array}{l}\text { Irrespective of } \\
\text { strike }\end{array}$ \\
\hline Drive with dip & Drive against dip & \multicolumn{2}{l|}{} \\
\hline Dip & Dip & Dip & Dip & Dip & Dip \\
\hline $45-90^{\circ}$ & $20-45^{\circ}$ & $45-90^{\circ}$ & $20-45^{\circ}$ & $45-90^{\circ}$ & $20-45^{\circ}$ & $0-20^{\circ}$ \\
\hline $\begin{array}{l}\text { Very } \\
\text { favourable }\end{array}$ & Favourable & Fair & Unfavourable & Very Unfavourable & Fair & Unfavourable \\
\hline
\end{tabular}

\subsection{Engineering Properties of Rocks}

For engineering group classification, plutonic rocks of Yuksekova Formation in the study area were evaluated as granite group, hypabyssal rocks in the region as porphyry group, and andesite as basalt group according to classification based on Mclean (2005) and BS 3618 (1971). In terms of engineering properties, Kuscular Formation is in gritstone group, Seske Formation in limestone group, Kirkgecit Formation also in gritstone and limestone group. The porosity of igneous rocks is less than $1.5 \%$ and is controlled by cracks. Again, the porosity is affected by the gravel size and composition of the gravel pieces and matrix in the Kuscular conglomerate. Porous rocks are easier to excavate than non-porous ones (Clark 1996). Rocks that have fractures are easier to excavate than those non-fracture. The grain size is also important in the productivity of a bulldozer according to MacGregor et al. (1994). The more

22 | P a g e www.iiste.org 
small grains rocks have, the more difficult rocks excavate. Furthermore, volcanic rock with the same characteristics is more difficult to excavate than hypabyssal rocks having bigger grains and plutonic rocks that have the biggest grains. Besides, it has been known that weathering of the rock mass or discontinuity surfaces make excavation easier. Furthermore, serrated and segmented discontinuities are more difficult to excavate than those polished and slickensided. Some engineering properties of the rocks are shown in Table 2. The order of excavatability of the rocks in the study area shows in Table 3 and Figure 6 when considered into the parameters given by MacGregor et al. (1994). The order of excavatability of rocks from hard to easy can be expressed as micro-diorite, granite, andesite and diorite of Yuksekova Formation, the conglomerate and sandstone of Kirkgecit Formation and the conglomerate of Kuscular Formation, and then the limestone and shale of Kirkgecit Formation would be excavated easily. When examined the formations exposed in the region according to the parameters of Weaver (1975), Yuksekova Formation requires to excavate method of extremely hard ripping and blasting, Kuscular Formation hard ripping, Seske Formation very hard ripping, and Kirkgecit Formation hard to very hard ripping (Table 4 and Figure 7). When being assessed lower and upper discontinuity spacing index and point load strength values and taken into consideration formations exposed in the field and these parameters are put on the graph of excavatability of Pettifer and Fookes (1994), it would be revealed that Yuksekova Formation requires methods that can be excavated by very hard, extremely hard ripping (D 9) or blasting. Kuscular Formation can be excavated by methods of easy ripping (D 6-D 7) to hard ripping (D 8). Seske Formation would be excavated by the equipment of easy ripping (D 6-D 7) and very hard ripping (D 9) and Kirkgecit Formation also hard digging (CAT 245) to very hard ripping (D 9) (Figure 8).

Table 2. Some engineering geology properties of rocks in the study area (UCS=24 I $\left.{ }_{s} 50\right)$.

\begin{tabular}{|c|c|c|c|c|c|c|}
\hline Formation & Rocks & $\begin{array}{l}\text { Grain } \\
\text { size } \\
(\mathrm{mm})\end{array}$ & $\begin{array}{c}\text { Porosity } \\
\%\end{array}$ & $\begin{array}{c}\text { Unconfined } \\
\text { Compressive } \\
\text { Strength } \\
\text { (UCS) (MPa) } \\
\end{array}$ & $\begin{array}{c}\text { Point load } \\
\text { strength } \\
\left(\mathrm{I}_{\mathrm{s} 50}\right)(\mathrm{MPa})\end{array}$ & $\begin{array}{l}\text { Discontinuity } \\
\text { spacing } \\
\text { index }(\mathrm{mm})\end{array}$ \\
\hline \multirow{4}{*}{ YUKSEKOVA } & Granit & $5-30$ & $0.3-0.8$ & $100-240$ & $4.1-10$ & \multirow{4}{*}{$1000-300$} \\
\hline & Diorite & $5-30$ & $0.3-0.8$ & $100-250$ & $4.1-12.5$ & \\
\hline & Microdiorite & $<1$ & $0.2-1$ & $120-300$ & $5-12.5$ & \\
\hline & Andesite & $<0$ & $0.2-1$ & $100-300$ & $4.1-12.5$ & \\
\hline KUSCULAR & Conglomerate & $20-60$ & $1-20$ & $50-100$ & $2.08-4.1$ & $300-50$ \\
\hline SESKE & Limestone & $<0.06$ & $0-10$ & $60-200$ & $2.5-8.2$ & $300-50$ \\
\hline \multirow{4}{*}{ KIRKGECIT } & Conglomerate & $20-60$ & $1-20$ & 60 & 2.5 & \multirow{4}{*}{$300-50$} \\
\hline & Sandstone & $0.06-2$ & $5-25$ & $30-179$ & $1.25-7.45$ & \\
\hline & Shale & $<0.06$ & $10-35$ & $5-100$ & $0.2-4.1$ & \\
\hline & Limestone & $<0.06$ & $0-10$ & $60-200$ & $2.5-8.2$ & \\
\hline $\begin{array}{l}\text { SURFICIAL } \\
\text { DEPOSITS }\end{array}$ & $\begin{array}{l}\text { Alluvium, } \\
\text { Talus }\end{array}$ & $\begin{array}{l}<0.06- \\
600\end{array}$ & $>40$ & & $\sim 0.18$ & \\
\hline
\end{tabular}


International Journal of Scientific and Technological Research

ISSN 2422-8702 (Online), DOI: 10.7176/JSTR/7-02-03

Vol.7, No.2, 2021

Table 3. Assessment of formations in study area according to parameters of MacGregor et al. (1994).

\begin{tabular}{|c|c|c|c|c|c|c|c|c|c|c|}
\hline Formation & Yuk & rsek & ova & & Kuscular & Seske & & Kirkge & & \\
\hline $\begin{array}{lll}\text { Rating } & \text { Rocks } \\
\end{array}$ & $\mathrm{G}^{*}$ & $\mathrm{D}^{*}$ & $\mathrm{M}^{*}$ & $\mathrm{~A}^{*}$ & Conglomerate & Limestone & Conglomerate & Sandstone & Shale & Limestone \\
\hline Rock type & 19 & 18 & 18 & 18 & 6 & 10 & 6 & 10 & 1 & 10 \\
\hline Grain size & 3 & 3 & 2 & 1 & $6-7$ & 1 & $6-7$ & $2-4$ & 1 & 1 \\
\hline Weathering & 3 & 4 & 3 & 6 & 3 & 1 & 3 & 1 & 1 & 1 \\
\hline Bedding & 1 & 1 & 6 & 1 & $3-5$ & $1-6$ & 8 & 8 & 6 & $1-6$ \\
\hline Strength & 1 & 1 & 2 & 2 & 3 & 2 & 3 & $2-4$ & $2-8$ & 2 \\
\hline Roughness & 3 & 2 & 3 & 2 & 3 & 1 & 3 & 2 & 2 & 1 \\
\hline Total & 30 & 29 & 34 & 30 & 24-27 & $16-21$ & $29-30$ & $25-29$ & 13-19 & $16-21$ \\
\hline
\end{tabular}

*G: Granite, D: Diorite, M: Microdiorite, A: Andesite.

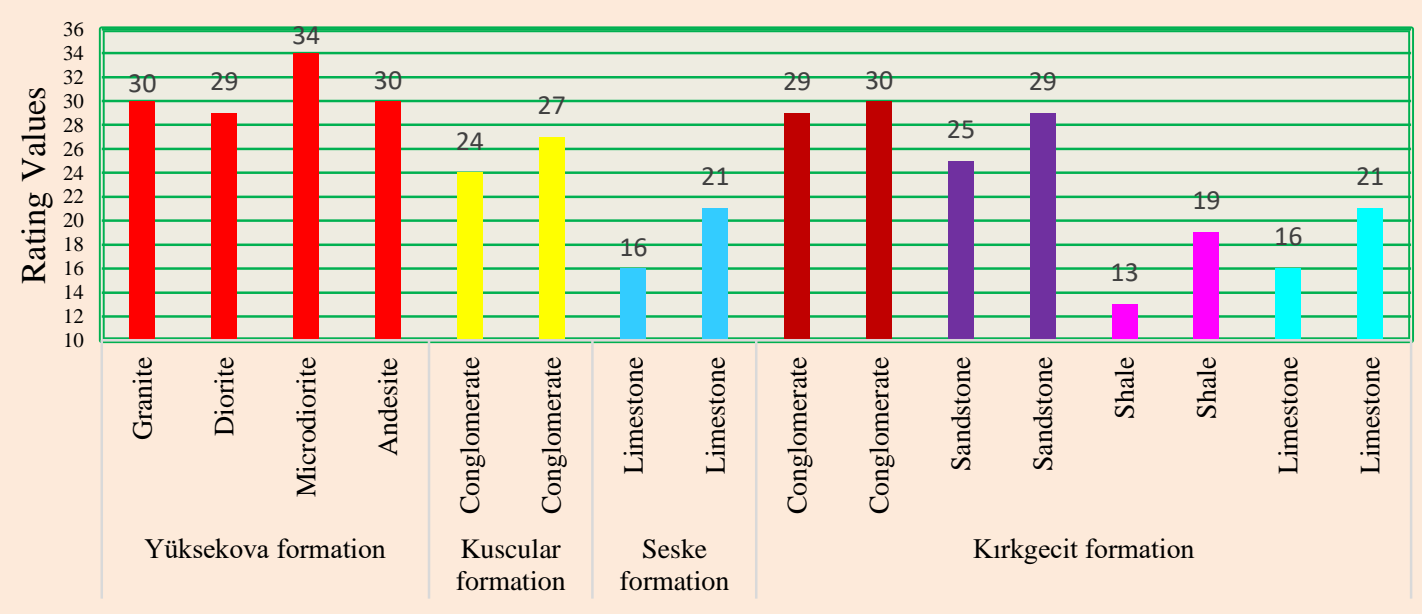

Figure 6: Excavatability rating values of formations in the study area according to parameters of MacGregor et al. (1994). 
International Journal of Scientific and Technological Research

ISSN 2422-8702 (Online), DOI: 10.7176/JSTR/7-02-03

Vol.7, No.2, 2021

Table 4. Rippability rating chart of rocks in study area (Weaver, 1975)

\begin{tabular}{|c|c|c|c|c|}
\hline Formation & Yuksekova & Kuscular & Seske & Kirkgecit \\
\hline $\begin{array}{l}\text { Seismic } \\
\text { velocity }(\mathrm{m} / \mathrm{s})\end{array}$ & $>2150$ to 1500 & $1500-1200$ & $>2150-1850$ & $>2150-1850$ \\
\hline Rating & $26-20$ & 12 & 24 & 24-12 \\
\hline \multirow{2}{*}{$\begin{array}{l}\text { Rock hardness } \\
(\mathrm{MPa})\end{array}$} & $\begin{array}{l}\text { Extremely hard } \\
\text { rock }\end{array}$ & Soft rock & Hard rock & $\begin{array}{l}\text { Very hard rock- } \\
\text { Poor rock }\end{array}$ \\
\hline & $>70$ to 20 & $10-3$ & $70-20$ & $70-20$ \\
\hline Rating & $10-2$ & 1 & 2 & 2 \\
\hline $\begin{array}{l}\text { Rock } \\
\text { weathering }\end{array}$ & $\begin{array}{l}\text { Unweathered to } \\
\text { weathered }\end{array}$ & $\begin{array}{l}\text { Slightly } \\
\text { weathered }\end{array}$ & Unweathered & $\begin{array}{l}\text { Slightly } \\
\text { Weathered }\end{array}$ \\
\hline Rating & $9-5$ & 7 & 9 & 7 \\
\hline \begin{tabular}{|l} 
Joint \\
spacing $(\mathrm{mm})$ \\
\end{tabular} & $1000-300$ & $300-50$ & $300-50$ & $300-50$ \\
\hline Rating & 20 & 10 & 10 & 10 \\
\hline Joint capacity & $\begin{array}{l}\text { Non-continuous } \\
\text { Continuous- } \\
\text { some-gouge }\end{array}$ & $\begin{array}{l}\text { Non- } \\
\text { continuous }\end{array}$ & $\begin{array}{l}\text { Continuous-no } \\
\text { gouge }\end{array}$ & $\begin{array}{l}\text { Continuous-no } \\
\text { gouge }\end{array}$ \\
\hline Rating & $5-0$ & 5 & 3 & 3 \\
\hline Joint gouge & Gouge $<5 \mathrm{~mm}$ & $\begin{array}{l}\text { Slight } \\
\text { separation }\end{array}$ & $\begin{array}{l}\text { Separation }<1 \\
\mathrm{~mm}\end{array}$ & $\begin{array}{l}\text { Separation }<1 \\
\mathrm{~mm}\end{array}$ \\
\hline Rating & 3 & 5 & 4 & 4 \\
\hline $\begin{array}{l}\text { Strike and dip } \\
\text { orientation }\end{array}$ & $\begin{array}{l}\text { Slightly } \\
\text { unfavorable }\end{array}$ & $\begin{array}{l}\text { Slightly } \\
\text { unfavorable }\end{array}$ & Favorable & Favorable \\
\hline Rating & 10 & 10 & 5 & 5 \\
\hline Total rating & $77-51$ & $50-40$ & 53 & $55-43$ \\
\hline $\begin{array}{l}\text { Rippability } \\
\text { assessment }\end{array}$ & $\begin{array}{l}\text { Extremely hard } \\
\text { ripping and } \\
\text { blasting }\end{array}$ & hard ripping & $\begin{array}{l}\text { Very hard } \\
\text { ripping }\end{array}$ & $\begin{array}{l}\text { Hard ripping - } \\
\text { very hard } \\
\text { ripping }\end{array}$ \\
\hline $\begin{array}{l}\text { Tractor } \\
\text { selection }\end{array}$ & - & D8/D7 & D9/D8 & D9/D7 \\
\hline Horsepower & - & $270 / 180$ & $385 / 270$ & $385 / 180$ \\
\hline Kilowatts & - & $200 / 135$ & $290 / 200$ & $290 / 135$ \\
\hline
\end{tabular}

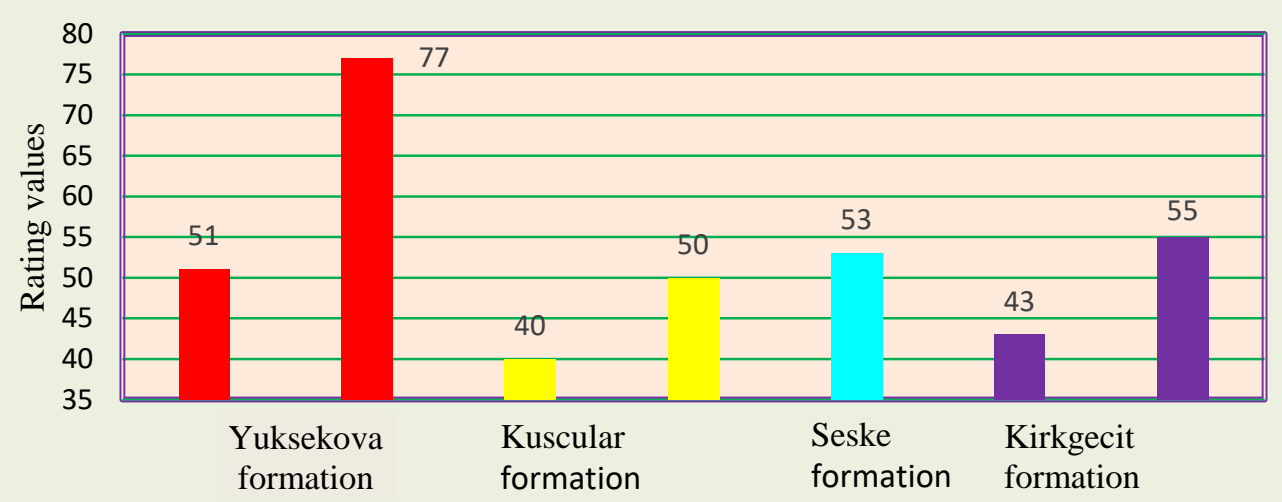

Figure 7: Rippability rating values of formations in study area relative to the parameters of Weaver, (1975) 


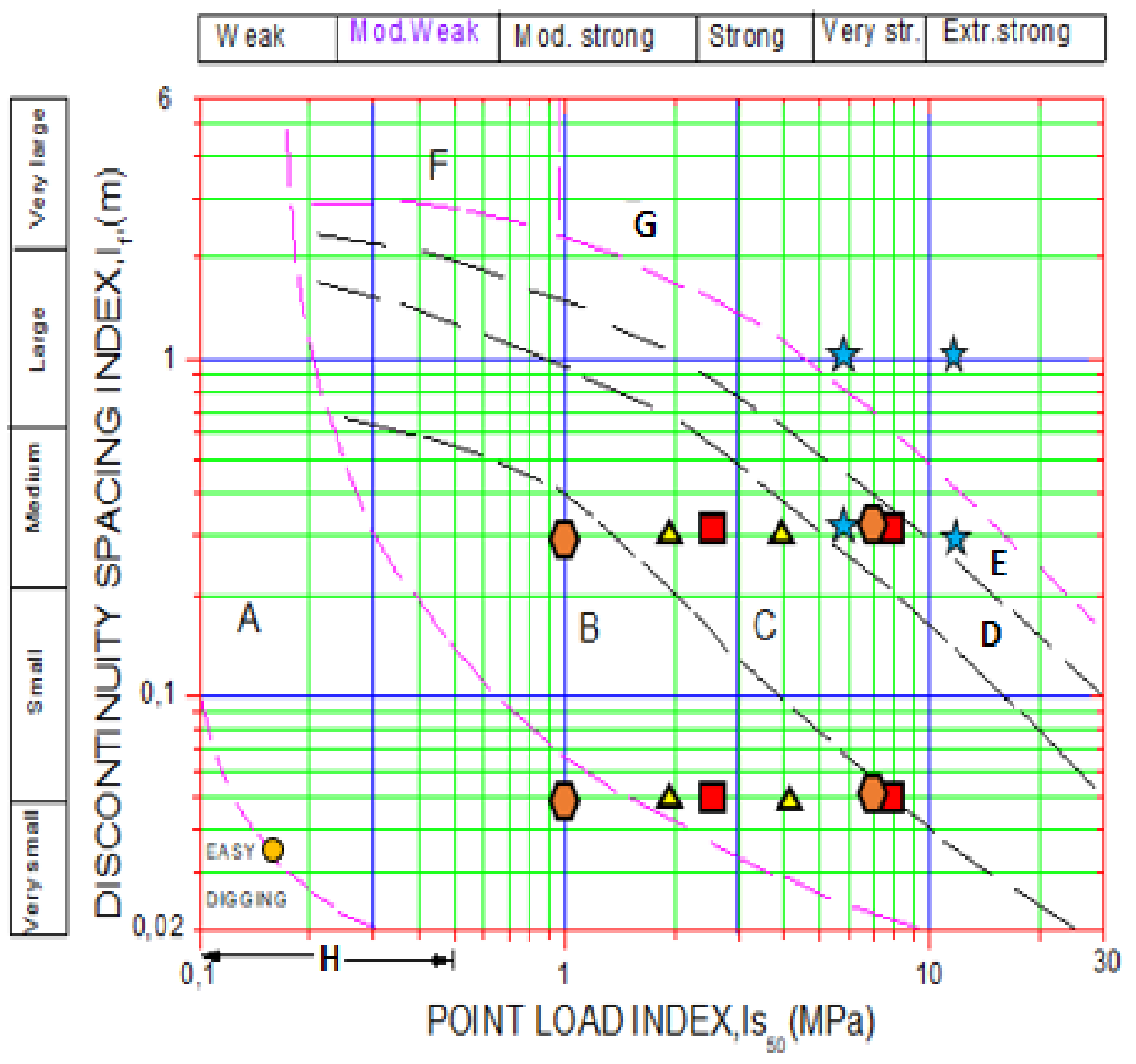

Figure 8. The representation on the graph of excavatability of Pettifer and Fookes (1994) of the rocks exposed in the study areas $\widehat{\jmath}$ : Yuksekova Formation $\triangle$ : Kuscular Formation, $\square$ :Seske Formation,

:Kirkgecit Formation andO :Surficial deposits, A: Hard digging(CAT 245 backhoe or face shovel),

B: Easy ripping (D 6-D 7), C: Hard ripping (D 8), D: Very Hard Ripping(D 9), E: Extremely hard ripping (D 11or Hydraulic breaking+D 9), F: blasting or hydraulic braking+ripping (e.g. D 9) or digging(e.g. face shovel), G: Blasting and $\mathbf{H}$ : Preferable to assess strength for these weaker rocks

\section{Conclusion}

Yuksekova Formation, Seske Formation, Kuscular Formation, Kirkgecit Formation, and surficial deposits outcrop in the region from old to young. They consist of igneous and sedimentary rocks. The fractures extend in the NNE direction over the rocks in the field. The strength of the rocks was evaluated in the range of medium to extremely strong. It was determined that an excavation in the orientation of $\mathrm{K} 60 \mathrm{~W}$ based on the discontinuity attitudes was the orientation of a very favorable excavation. Also, the orientation of a very unfavorable excavation is the azimuth of the strike of fracture, namely the direction N30E. It was seen that the conglomerate and sandstone of Kirkgecit Formation had a high rating in the excavatability column graph drawn by calculating the rating of excavatability parameters of the rocks in the study area. It is thought this is the result of the fact that the conglomerate and sandstone in the Kirkgecit Formation both are silica-cemented and the component elements have the rock fragments that originated from Yuksekova Formation. When have been calculated relative to the parameters such as the seismic velocity, hardness and weathering of rock and the spacing, capacity, gouge, the strike and dip azimuth of joint, Yuksekova Formation is required to excavate the method of extremely hard ripping and blasting, Kuscular conglomerate hard ripping, Seske Formation very hard ripping and Kirkgecit Formation hard to very hard ripping. When being assessed lower and upper discontinuity spacing index and point load strength values and taken into consideration formations exposed in the field, however, it was determined that Yuksekova Formation requires methods that can be excavated from very hard to extremely hard ripping (D 9) -blasting. Again, Kuscular Formation can be excavated by easy ripping (D 6-D 7) to hard ripping (D 8) methods.

26 | P a g e

www.iiste.org 
Besides, Seske Formation would be excavated by easy ripping (D 6-D 7)-very hard ripping (D 9) equipment. Kirkgecit Formation has the capabilities of being excavated by hard digging (CAT 245) to very hard ripping (D 9) methods. Nevertheless, the order of excavatability as rocks can be expressed from hard to easy as micro-diorite, granite, andesite, diorite, the conglomerate of Kirkgecit Formation, Kuscular conglomerate, and then the limestone and shale of Kirkgecit Formation would be excavated easily respectively. The surficial deposits can be also excavated optimally by the digging method. The results show that the most appropriate method for the accuracy of the feasibility evaluations should be examined the excavations of the rocks with more than one method by comparing the results of methods used. Depending on the situations encountered during the excavation, it can be suggested to use the best or worst excavatability rating values for the rocks evaluated by these methods, whichever is appropriate.

\section{References}

Abdullatif, O. M. \& Cruden, D. M. (1983), "The relationship between rock mass quality and ease of excavation.” Bull. Eng. Geol. Environ. 28,183-187.

Asutay, H. J. (1985), "Geology of the Baskil (Elazig) area and the petrology of Baskil magmatics", PhD thesis, A. U. Science Inst., ANKARA.

Bell, F. G. (2007), "Engineering Geology”, ISBN-13978-0-7506-8077-6, www. Elsevier.com., Britain.

Bieniawski, Z.T. (1989), "Engineering Rock Mass Classifications" A Complete Manual For Engineers and Geologists in Mining) Civil) and Petroleum Engineering, John Wiley and Sons, New York, 251 pages.

Blyth, F. G. H., Freitas \& M. H. De (1984), “A Geology for Engineers” Elsevier, ISBN 07131 2882 8, London.

BS 3618, (1971), "British Standards Institution, Glossary of mining terms”, Section 5: Geology. Br. Stand. Inst. Rep. B, Britain.

Clark, P.B. (1996), "Rock mass and rippability evaluation for a proposed open pit mine at GlobeProgress, near Reefton" University of Canterbury, Master thesis.

Franklin, J. A., Broch, E. \& Walton G. (1971), "Logging the mechanical character of rock", Trans. Inst. Min. Metall, volume 80A, 1-9.

ISRM (1981), "Rock Characterization Testing and Monitoring”, International Society for Rock Mechanics Suggested Methods E.T. Brown (editor), Pergamon Press, Oxford, 211.

MacGregor, F., Fell, R., Mostyn, G.R., Hocking G. \& McNally G. 1994 “The estimation of rock rippability”, Quarterly Journal of Engineering Geology, volume 27, pages 123-144.

Mclean, A. C., Gribble, C. D. (2005), "Geology for Civil Engineer”, in the Taylor \& Francis eLibrary, www.eBookstore.tandf.co.uk.

Pettifer, G. S. \& Fookes, P. G. (1994), "A revision of the graphical method for assessing the excavatability of rock", Q. J. Eng. Geol. 27:145-164.

Tatar, Y. (1986), "Tectonic features of the Euphrates basin: Symposium on geology and underground riches of the Euphrates basin around Elazig" (unpublished), F. U. Eng. Fak. Geo. Eng., ELAZIG,.

Weaver, J. M. (1975), "Geological factors significant in the assessment of rippability", Transactions of the South African Institute of Civil Engineers, volume 17, 313-316. 